\title{
Rheumatoid lung nodule
}

\author{
Parikshit Sagdeo, Yathish Gattimallanahali, Girish Kakade, Balakrishnan Canchi
}

Department of Rheumatology, PD Hinduja Hospital and Medical Research Centre, Mumbai, Maharashtra, India

\section{Correspondence to} Dr Yathish Gattimallanahali, yathish_gc@yahoo.co.in

Accepted 15 October 2015

\section{(a) CrossMark}

To cite: Sagdeo $P$ Gattimallanahali $Y$

Kakade G, et al. BMJ Case Rep Published online: [please include Day Month Year] doi:10.1136/bcr-2015213083

\section{DESCRIPTION}

A 61-year-old woman was under treatment with a combination of methotrexate and leflunomide for seropositive rheumatoid arthritis (RA) for the past 6 years. She presented to us 6 months earlier with grade 1 dyspnoea of 3 -month duration. She was a non-smoker. On evaluation, her vitals, and respiratory and cardiovascular system were normal. Laboratory reports revealed normal blood count, and renal and liver function tests were also normal. Chest X-ray revealed multiple nodules (in left upper lobe and right lower lobe). CT of the chest confirmed bilateral multiple necrotic and nonnecrotic nodules (figures 1 and 2). Since the differential diagnoses included opportunistic infections and malignancy, a CT-guided biopsy was performed. Histopathology showed necrotising inflammation consisting of collections of macrophages, lymphocytes and plasma cells around the area of necrosis, without evidence of vasculitis or malignancy. Cultures did not grow fungus or mycobacteria. A diagnosis of rheumatoid nodule was made based on the clinical setting, typical radiographic, histopathology features and negative cultures. Follow-up scans carried out 3 months later did not show worsening or new nodules.

Pulmonary rheumatoid nodules are rare and their prevalence ranges from $<0.4 \%$ in radiological studies to $32 \%$ in lung biopsies of patients with RA and nodules. ${ }^{1}$ They are more frequent in male patients with positive rheumatoid factor, smokers, patients with subcutaneous nodules and those on long-term treatment with methotrexate. They are usually multiple and rounded. In several cases, solitary pulmonary nodules in patients with RA have proved to be a rheumatoid nodule and a coexistent bronchogenic carcinoma. ${ }^{2}$ If the index of suspicion is high for malignancy, the work up should be more aggressive. They are preferentially located in

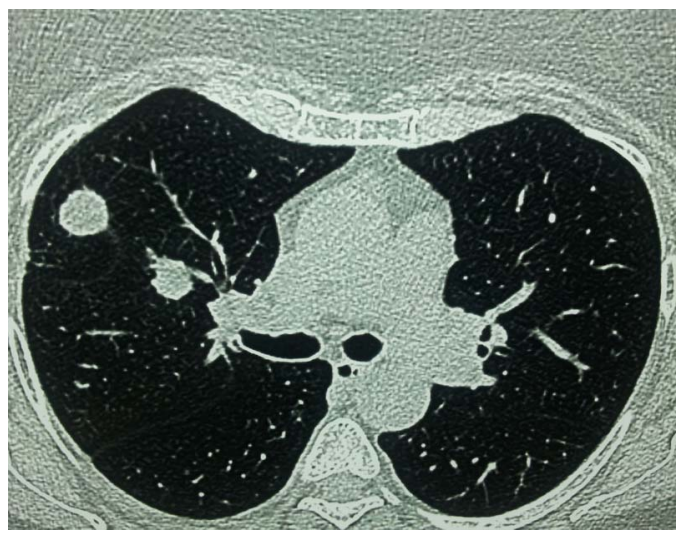

Figure 1 Chest CT: axial image showing multiple rheumatoid nodules.

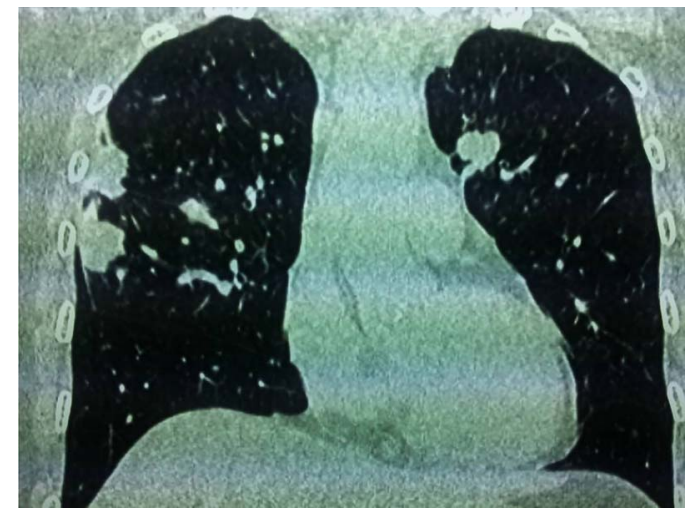

Figure 2 Chest CT: coronal reformatted image showing multiple rheumatoid nodules.

the middle and superior peripheral lobe or pleural based with a size ranging from a few millimetres to $7 \mathrm{~cm}$. Up to $50 \%$ may cavitate and be accompanied by an associated pleural effusion, pneumothorax or hydropneumothorax. They may appear and evolve or regress without any relation to the evolution of arthritis. They are mostly asymptomatic and, in most cases, do not require specific treatment. ${ }^{2}$ Typical histopathological findings of rheumatoid lung nodules consist of central zone of acellular fibrinoid necrosis surrounded by a zone of palisading epithelioid cells, which in turn are surrounded by a collar of lymphocytes, plasma cells and fibroblasts. ${ }^{3}$ Although these typical features were not seen on histopathology, the biopsy essentially ruled out other causes such as malignancy and infection, making the diagnosis of rheumatoid nodule with a high degree of certainty in the reported case.

\section{Learning points}

- Rheumatoid lung nodules are rare pulmonary manifestations of rheumatoid arthritis.

- They are usually asymptomatic and seen in longstanding sero-positive cases and/or in those on prolonged therapy with methotrexate.

- Biopsy is mandatory in such cases, to rule out infections and malignancy.

Twitter Follow Yathish Gattimallanahali at @yathishgc45

Competing interests None declared.

Patient consent Obtained.

Provenance and peer review Not commissioned; externally peer reviewed. 


\section{REFERENCES}

1 Yousem SA, Colby TV, Carrington CB. Lung biopsy in rheumatoid arthritis. Am Rev Respir Dis 1985;131:770-7.
2 Shenberger KN, Schned AR, Taylor TH. Rheumatoid disease and bronchogenic carcinoma-case report and review of the literature. J Rheumatol 1984;11:226-8. 3 Ziff M. The rheumatoid nodule. Arthritis Rheum 1990;33:761-7.

Copyright 2015 BMJ Publishing Group. All rights reserved. For permission to reuse any of this content visit http://group.bmj.com/group/rights-licensing/permissions.

BMJ Case Report Fellows may re-use this article for personal use and teaching without any further permission.

Become a Fellow of BMJ Case Reports today and you can:

- Submit as many cases as you like

- Enjoy fast sympathetic peer review and rapid publication of accepted articles

- Access all the published articles

- Re-use any of the published material for personal use and teaching without further permission

For information on Institutional Fellowships contact consortiasales@bmjgroup.com

Visit casereports.bmj.com for more articles like this and to become a Fellow 